\title{
THE DIAGNOSTIC SYSTEM OF A - 604 AUTOMATIC TRANSMISSION
}

\author{
Jaroslaw CZABAN*, Dariusz SZPICA* \\ ${ }^{*}$ Faculty of Mechanical Engineering, Department of Mechanical Engineering, Bialystok University of Technology, \\ ul. Wiejska 45C, 15 - 351 Białystok, Poland \\ j.czaban@pb.edu.pl, d.szpica@pb.edu.pl
}

\begin{abstract}
Automatic gearbox gains increasing popularity in Europe. Little interest in diagnosis of such type of transmission in Poland results from the fact of small share in the whole market of operated cars, so there is a lack of availability of special diagnostic devices. These factors cause issues of expensive repairs, often involving a replacement of subassembly to new or aftermarket one. To a small extent some prophylactic diagnostic tests are conducted, which can eliminate future gearbox system failures. In the paper, the proposition of diagnostic system of popular A - 604 gearbox was presented. The authors are seeking for the possibility of using such type of devices to functional elaboration of gearboxes after renovation. The built system pursues the drive of the researched object, connected with simulated load, where special controller, replacing the original one, is responsible for controlling gearbox operation. This way is used to evaluate the mechanic and hydraulic parts' state. Analysis of signal runs, registered during measurements lets conclude about operation correctness, where as comparison with stock data verifies the technical state of an automatic gearbox.
\end{abstract}

Key words: Automatic Transmission, Diagnosis, Research

\section{INTRODUCTION}

An automatic transmission is the car gearbox which shifts gears with the change of load and rotational speed of the car engine, releasing the driver from the necessity of manual shifts. This allows very smooth ride, by optimizing the load to the engine rotational speed. Thus the cars equipped with such type of gearbox reach higher mileages, because the engine is less loaded. The automatic transmission is the most popular in the United States of America, but it gains popularity also in Europe. It is estimated that the share of vehicles with automatic gearbox in the American market is ca. $90 \%$, whereas in Europe it is only $27 \%$ (including continuously variable transmissions, semi - automatic and double - clutch gearboxes) (Ślaski, 2010). Even smaller popularity in Poland is due to increased fuel consumption, significant operation costs and eventual repair and higher price of vehicles equipped with automatic gearbox.

In last past years the significant technical development occurred in the field of electronics and control systems, which also got into automatic transmission control systems (Bosch, 2005). Electronic control of these systems significantly simplified the hydraulic block (divider) design and allowed to diagnose the technical state of transmission by means of OBDII/EOBD socket and code readings from the P07xx group (Sobieraj, 2005; Merkisz et al., 2006). Small interest in diagnosis of such transmission type results from the fact of small share in the whole market of operated cars, so there is a lack of availability of special diagnostic devices in Poland. These factors cause issues of expensive repairs, often involving a replacement of subassembly to new or aftermarket one. This situation takes place also in dealer service garages. To a small extent some prophylactic diagnostic tests are conducted, which can eliminate future gearbox system failures.

In spite of the electronics development, the automatic gearbox still remained complex mechanical and diagnostic object and is characterized by complexity of processes performing inside it. As its basic assemblies - converter, planetary gearings, clutches and brakes, hydraulic block, solenoid valves and control system with sensors can be counted. These subsystems can be subjected to failures making it completely impossible for transmission to work or causing its improper operation. The basic assemblies failures are: damage of the fluid coupling (converter), wear of clutches or brakes realizing proper gearings, galling and leaks in valve body, solenoid valve or sensor failures or even the controller failures (Chrysler, Sobieraj, 2005). Accurate diagnose of failures and technical state of automatic gearbox significantly reduces repair time and cost.

As an aim, the elaboration of diagnostic stand of automatic transmission after major renovation was stated. The built system enables drive and load application on researched object, with simultaneous controlling its working parameters via special controller, which replaces the original one. The stand can meet broad usage in plants dealing with renovation of automatic gearboxes.

\section{THE DIAGNOSTIC TESTING METHODS OF AUTOMATIC GEARBOXES OPERATION}

Already in construction and preliminary research course of automatic transmission there are many factors taken into account, which can influence on powertrain functioning. Multi - surface optimization must reconcile the performance with the riding comfort and, what is recently very important - with ecology of the powertrain (Bemporad et al., 2003). The simulation research allows setting the preliminary automatic transmission configuration (Haj - Fraj et al., 2001), the problem is to optimize the control algorithm. For a few years there are available on the market classic gearboxes eqiupped with double clutches, which are able to shift in automatic cycle (Walker et al., 2001), however also in this 
case the biggest challenge is the control algorithm. Automatic gearbox and mechanical gearbox with double clutch have one thing in common - synchronization of clutches operation (Wen Miin et al., 2011). The transition process connected to gear shift decides about dynamic characteristics, as well as operational capabilities (Kulkarni et al., 2007).

There are many methods which form the basis to verify the transmission operational state. The part of them bases on the sensors mounted inside the gearbox and basing on them the functioning is evaluated (Remond et all, 1998), pointing at failure source in the sensors themselves. The other group of methods is the spectral analysis of vibrations generated by powertrain (Rumble et al., 2000), where by using the signal processing the gearing parameters are optimized (Bozca, 2010). The transmission durability is also predicted by estimation of bearing capacity (Ognjanovic et al., 2013).

The research stands elaborating operational capabilities of gearboxes are produced in different configurations. Basic solutions provide the diagnostic sets dedicated to the workshops dealing with repairs (Power Test, Superflow, Mustangdyne, Klotz), the second group consists of research stands, which are used by vehicle producers, for example Adigitec, whereas to the group of the most advanced solutions can be counted The FEV Group solution. The operation of all of these stands is similar, in every case there is necessary to propel the transmission input shaft, while on the other side to brake on the output shaft to generate the torque inside the researched object. The stands based on specific transmission model are also made, in which the internal combustion engine is used for propelling (Ślaski et al., 2011; Ślaski, 2010; Ślaski, 2012). Such type of solutions reflects the real conditions at the highest level, because the transmission is subjected to the variable loads. They are the result of power unit work periodicity. The problem is the universality, i.e. the ability of usage to the other testing object.

\section{A - 604 AUTOMATIC GEARBOX}

Automatic gearbox A - 604 made in the USA was mounted in Chrysler vehicles since 90s till present day. It was the equipment of cars with engines with the displacement 2.5 to $3.8 \mathrm{~L}$. Depending on the engine displacement the A - 604 gearboxes had small differences in mounting points.

Automatic gearboxes A - 604 as first, according to producer's information, were equipped with adaptive control system, which by reading the throttle position data and vehicle speed, was selecting the gearing. The gearing selection is performed by solenoid valves operation, which control the hydraulic actuating system. The scheme of $A-604$ automatic transmission was presented in Fig. 1. The specific construction of exact gearbox subsystems can be found in Chrysler's Automatic Transmission Service Group documentation.

The $A-604$ gearbox has four forward gears and one reverse gear. The selector range can be positioned in five positions: $P, R$, $N, D, L$. The $D$ range is used for daily driving. The $L$ range is used for driving in mountain and sinuous roads, because it allows the engine braking. In the case of these two positions, for better transmission oil cooling, the lock - up engage occurs.

The selection of clutches is performed by the solenoid valve block controlled by the electric signal. In table 2 the powering states of solenoid valves for individual gearing are presented.
The transition of state and the time of pressure increase in clutches is the coupling time.

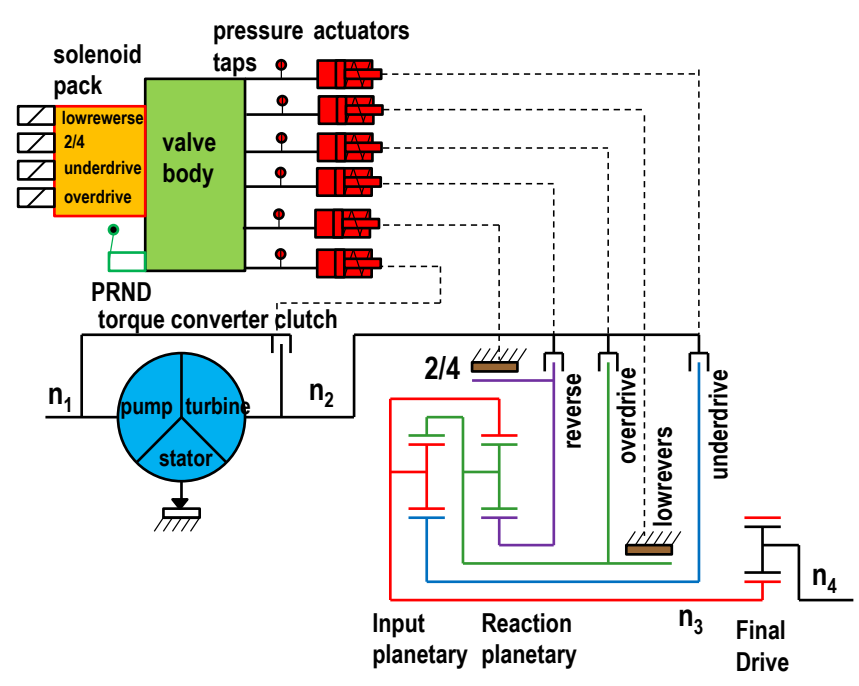

Fig. 1. A - 604 automatic gearbox scheme

The gearing change performs by means of established cooperation of individual clutches. In Tab. 1 the list of engaged clutches depending on the selected gearing are presented.

Tab. 1. Kinds of cooperating clutches depending on gearing (Chrysler)

\begin{tabular}{|r|c|c|c|c|c|}
\hline \multirow{2}{*}{$\begin{array}{c}\text { Transsmision } \\
\text { operation } \\
\text { state }\end{array}$} & \multicolumn{5}{|c|}{ Clutch } \\
\cline { 2 - 5 } & $\begin{array}{c}\text { Under } \\
\text { drive }\end{array}$ & Overdrive & Reverse & $2 / 4$ & $\begin{array}{c}\text { Low } \\
\text { reverse }\end{array}$ \\
\hline Park & & & & & $\mathrm{X}$ \\
\hline Reverse & & & $\mathrm{X}$ & & $\mathrm{X}$ \\
\hline Neutral & & & & & $\mathrm{X}$ \\
\hline 1st & $\mathrm{X}$ & & & & $\mathrm{X}$ \\
\hline 2nd & $\mathrm{X}$ & & & $\mathrm{X}$ & \\
\hline 3rd & $\mathrm{X}$ & $\mathrm{X}$ & & & \\
\hline 4th & & $\mathrm{X}$ & & $\mathrm{X}$ & \\
\hline
\end{tabular}

Tab. 2. Solenoid valve states for individual gearings (Chrysler)

\begin{tabular}{|r|c|c|c|c|}
\hline \multirow{2}{*}{$\begin{array}{c}\text { Transmission } \\
\text { operation } \\
\text { state }\end{array}$} & \multicolumn{4}{|c|}{ Solenoid valve } \\
\hline & Lowreverse & $2 / 4$ & Underdrive & Overdrive \\
\hline Park & $\mathrm{X}$ & $\mathrm{X}$ & & \\
\hline Neutral & & $\mathrm{X}$ & & \\
\hline Reverse & & & & \\
\hline 1st & $\mathrm{X}$ & $\mathrm{X}$ & & \\
\hline 2nd & & & & \\
\hline 3rd & & $\mathrm{X}$ & & $\mathrm{X}$ \\
\hline 3rd+ lockup & $\mathrm{X}$ & $\mathrm{X}$ & & $\mathrm{X}$ \\
\hline 4th & & & $\mathrm{X}$ & $\mathrm{X}$ \\
\hline 4th+ lockup & $\mathrm{X}$ & & $\mathrm{X}$ & $\mathrm{X}$ \\
\hline
\end{tabular}

The oil pressure in clutches actuators: lowreverse, overdrive and $2 / 4$, of automatic gearbox is continuously monitored by the gearbox controller by means of pressure sensors in solenoid valve block. Below the sensor states for individual gearings are presented (Tab. 3). 
Tab. 3. Sensor states for individual gearings (Chrysler)

\begin{tabular}{|r|c|c|c|}
\hline $\begin{array}{c}\text { Transsmision } \\
\text { operation state }\end{array}$ & Lowreverse & $\mathbf{2 / 4}$ & Overdrive \\
\hline Park & 1 & 0 & 0 \\
\hline Reverse & 0 & 0 & 0 \\
\hline Neutral & 1 & 0 & 0 \\
\hline 1st & 1 & 0 & 0 \\
\hline 2nd & 0 & 1 & 0 \\
\hline 3rd & 0 & 0 & 1 \\
\hline 4th & 0 & 1 & 1 \\
\hline
\end{tabular}

The „zero” state means no pressure in individual clutch (no electrical signal). Whereas „one" means the specific pressure value (voltage).The pressure measurement can also be performed by pressure ports available in gearbox housing.

The gearbox controller is responsible for control of transmission operation. This device is coupled with engine control unit. The controller, basing on the range selector position, measured driving speed, engine rotational speed and converter's slip, engaged proper gear by energizing individual solenoid valves and by means of internal binary sensors of solenoid valve package checked if the pressure values occur in proper ports.

\section{TEST STAND FOR AUTOMATIC GEARBOX A - 604}

For estimating the technical state of automatic gearbox A 604 in Department of Construction and Operation of Machines the research stand was designed, which is showed in Fig. 2.

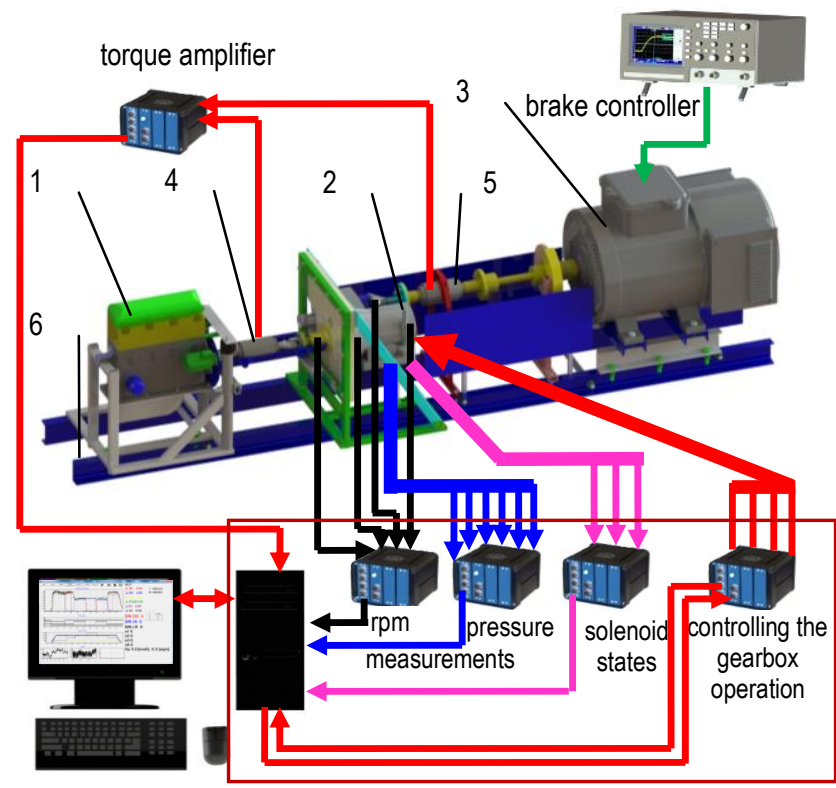

gearbox controller

Fig. 2. Test stand for $A-604$ automatic gearbox testing: 1 - propeller system, 2 - automatic transmission system, 3 - DC generator, 4, 5 - coupling shafts and torque sensors, 6 - stand frame

It consists of automatic gearbox assembly (2) mounted to the frame (6). For propelling the gearbox the XUD - 9 diesel internal combustion engine (1) was used, whereas for braking - DC generator (3). Propelling and load, which affect the gearbox, are transmitted by shafts and torque sensors $(4,5)$. The modular construction of the stand allows changing the propeller to electrical engine controlled by inverter, as well as dismantling the braking system.

To allow gear shifting in automatic gearbox and measurement data acquisition the specialized diagnostic controller was made, which is based on AtMega32 microcontroller. The block scheme of the controller is showed in Fig. 3. It consists of input module, to which the rotational speed sensors (7) are connected. They allow determining the engine rotational speed $n_{1}$, converter output speed $n_{2}$, planetary gearing assembly output speed $n_{3}$ and half shaft rotational speed $n_{4}$. Three solenoid valve block pressure sensors (9) were also connected to the module, as well as six pressure sensors in clutch actuators (11). For determining the position of range selector lever (10) the binary sensors of gearbox were used. The controller, by means of output module, controls the operation of the solenoids of valve block (8). The information about actual controller operation parameters are displayed on LCD screen (6). The gear shift can be performed automatically or manually.

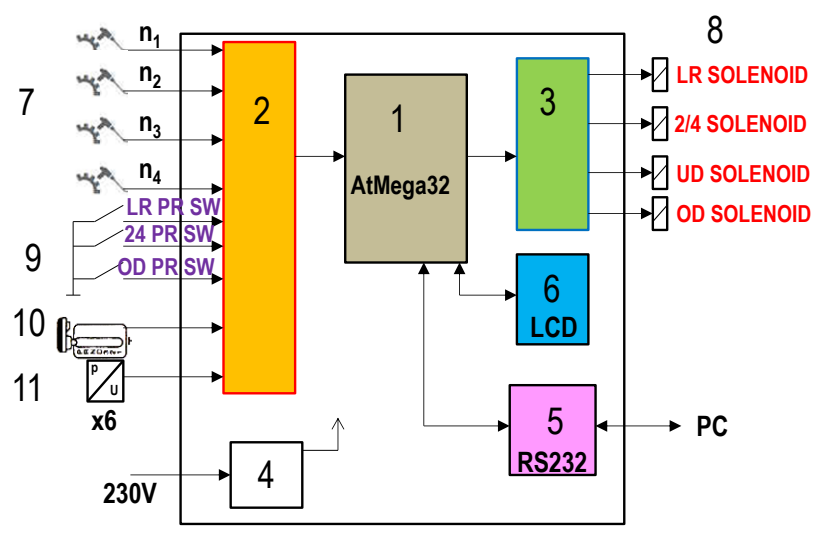

Fig. 3. Block scheme of the gearbox controller:

1 - AtMega32 microcontroller, 2 - input module, 3 - output module, 4 - power supply system, 5 - communication port, 6 - LCD screen, 7 - rotational speed sensors, 8 - solenoid valve block, 9 - solenoid valves pressure sensors, 10 - range selector lever sensor, 11 - pressure sensors inside actuators, (LR - Lowreverse, UD - Underdrive,OD - Overdrive)

For controlling the gearbox operation, measurement data acquisition and visualization the individual computer application "A604.exe" was made in Borland Delphi 3.0 programming environment (Fig. 4).

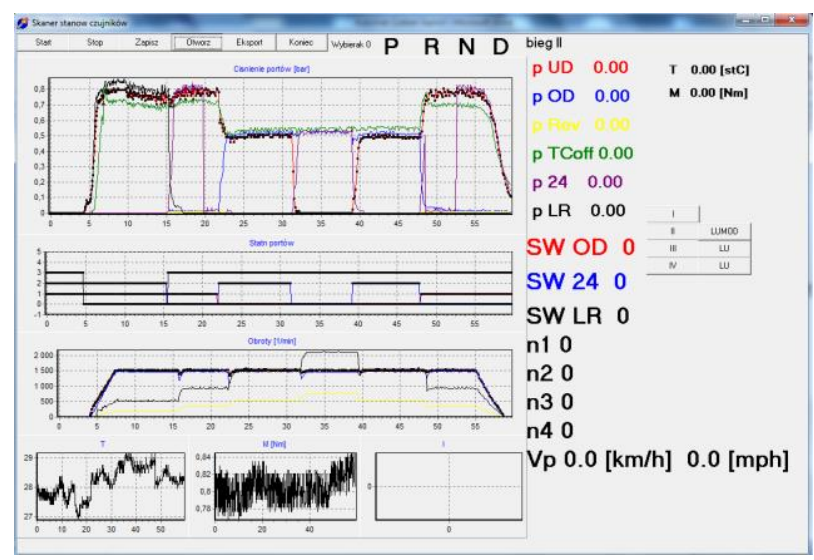

Fig. 4. "A604.exe" application - example of recorded measurement session 
The specific description of presented controller, which includes electronic systems schemes and applied algorithms saved in microcontroller, will be presented in next authors' publications.

\section{THE PROCEDURE OF DIAGNOSTIC RESEARCH ON THE STAND AND SAMPLE RESULTS}

The basic research, which enables the evaluation of mechanic and hydraulic systems operation of the gearbox, is the measurement of pressure values in specific actuators of clutch baskets and comparing them with nominal values given by producer (Tab. 4). The pressure courses also enable the evaluation of gearing changing process. To perform the evaluation, the research must be run for every possible operation modes of the automatic transmission and ensure proper rotational speed values for each of these modes. For correct conclusion about changing gearings, the research should be run both ways: increasing and decreasing.

The test was run on the gearbox after the major repair, which came from Chrysler Voyager with mileage ca. $160 \mathrm{k} \mathrm{km}$. In this gearbox the lowreverse clutch was replaced because of its crack. Taking into account the significant vehicle mileage, all clutch disc set and inner seals were also replaced.
In the test the electrical motor was used instead of internal combustion engine and the test under load was skipped. It was a result of the fact that it was necessary to lock up the differential., because the gearbox came from the vehicle with integrated drive assembly. The stand is dedicated to test the gearboxes from cars with classical drive assembly.

The test was run in accordance to producer's recommendation in oil temperature ca. $80^{\circ} \mathrm{C}$ and recommended vehicle longitudinal speeds on individual gearings. Rotational speeds with which the gearbox was propelled during research in selector positions $\mathrm{P}, \mathrm{R}$ and $\mathrm{N}$ was set to $1500 \mathrm{rpm}$.

Basing on the registered pressure courses in individual clutches actuators the average values of pressure during operation on individual gearings were stated. Gained results were set in Tab. 4. The values were within the ranges given by the producer.

During tests of researched gearbox, gearing changing was performed in robust way both directions: up and down. No differences were observed in time values of engaging specific gears. The research in 4th gear and with lockup clutch engaged did not result in any slips, what indicates the proper operation.

It was stated that the major renovation was done correctly and all elements of gearbox: mechanic and hydraulic ones, work properly and it can be mounted in the vehicle.

Tab. 4. Comparison of measured pressures with the producer's data ( ${ }^{*}$ Chrysler)

\begin{tabular}{|c|c|c|c|c|c|c|c|}
\hline \multirow{2}{*}{$\begin{array}{l}\text { Selector } \\
\text { range }\end{array}$} & \multirow{2}{*}{$\begin{array}{c}\text { Transmissio } \\
\text { n control } \\
\text { state }\end{array}$} & \multicolumn{6}{|c|}{ Pressure in clutch actuators [MPa] } \\
\hline & & Underdrive & Overdrive & Reverse & Lockup off & $2 / 4$ & Lowreverse \\
\hline$P$ & $P$ & $\begin{array}{c}0.00 \\
(0 \div 0.014)^{*}\end{array}$ & $\begin{array}{c}0.00 \\
(0 \div 0.034)^{*}\end{array}$ & $\begin{array}{c}0.00 \\
(0 \div 0.014)^{*}\end{array}$ & $\begin{array}{c}0.492 \\
(0.414 \div 0.758)^{*}\end{array}$ & $\begin{array}{c}0.00 \\
(0 \div 0.014)^{*}\end{array}$ & $\begin{array}{c}0.832 \\
(0.793 \div 0.99) \text { * }\end{array}$ \\
\hline $\mathrm{R}$ & $\mathrm{R}$ & $\begin{array}{c}0.00 \\
(0 \div 0.014)^{*}\end{array}$ & $\begin{array}{c}0.00 \\
(0 \div 0.048)^{*}\end{array}$ & $\begin{array}{c}1.195 \\
(1.14 \div 1.61)^{*}\end{array}$ & $\begin{array}{c}\mathbf{0 . 6 4 5} \\
(0.345 \div 0.689) *\end{array}$ & $\begin{array}{c}0.00 \\
(0 \div 0.014)^{*}\end{array}$ & $\begin{array}{c}1.148 \\
(1.14 \div 1.61)^{*}\end{array}$ \\
\hline $\mathrm{N}$ & $\mathrm{N}$ & $\begin{array}{c}0.00 \\
(0 \div 0.014)^{*}\end{array}$ & $\begin{array}{c}0.00 \\
(0 \div 0.034)^{*}\end{array}$ & $\begin{array}{c}\mathbf{0 . 0 0} \\
(0 \div 0.014)^{*}\end{array}$ & $\begin{array}{c}\mathbf{0 . 6 2 1} \\
(0.4137 \div 0.758) \text { * }\end{array}$ & $\begin{array}{c}0.00 \\
(0 \div 0.014) *\end{array}$ & $\begin{array}{c}0.878 \\
(0.793 \div 0.99) \text { * }\end{array}$ \\
\hline $\begin{array}{c}D \\
28 \mathrm{~km} / \mathrm{h}\end{array}$ & 1st & $\begin{array}{c}0.809 \\
(0.758 \div 0.99) \text { * }\end{array}$ & $\begin{array}{c}0.00 \\
(0 \div 0.034)^{*}\end{array}$ & $\begin{array}{c}0.00 \\
(0 \div 0.014)^{*}\end{array}$ & $\begin{array}{c}\mathbf{0 . 6 3 3} \\
(0.4137 \div 0.758) \text { * }\end{array}$ & $\begin{array}{c}0.00 \\
(0 \div 0.014)^{*}\end{array}$ & $\begin{array}{c}0.879 \\
(0.793 \div 0.99) \text { * }\end{array}$ \\
\hline $\begin{array}{c}D \\
56 \mathrm{~km} / \mathrm{h}\end{array}$ & 2nd & $\begin{array}{c}0.832 \\
(0.758 \div 0.99)^{*}\end{array}$ & $\begin{array}{c}0.00 \\
(0 \div 0.034)^{*}\end{array}$ & $\begin{array}{c}0.00 \\
(0 \div 0.014)^{*}\end{array}$ & $\begin{array}{c}0.656 \\
(0.4137 \div 0.758)\end{array}$ & $\begin{array}{c}0.855 \\
(0.793 \div 0.99) \text { * }\end{array}$ & $\begin{array}{c}\mathbf{0 . 0 0} \\
(0 \div 0.014) *\end{array}$ \\
\hline $\begin{array}{c}D \\
80 \mathrm{~km} / \mathrm{h}\end{array}$ & $3 \mathrm{rd}$ & $\begin{array}{c}0.516 \\
(0.517 \div 0.65)^{*}\end{array}$ & $\begin{array}{c}0.527 \\
(0.517 \div 0.65) \text { * }\end{array}$ & $\begin{array}{c}0.00 \\
(0 \div 0.014) *\end{array}$ & $\begin{array}{c}\mathbf{0 . 5 5 1} \\
(0.4137 \div 0.62) *\end{array}$ & $\begin{array}{c}0.00 \\
(0 \div 0.014) *\end{array}$ & $\begin{array}{c}0.00 \\
(0 \div 0.014) *\end{array}$ \\
\hline $\begin{array}{c}D \\
112 \mathrm{~km} / \mathrm{h}\end{array}$ & 4th & $\begin{array}{c}0.00 \\
(0 \div 0.014)^{*}\end{array}$ & $\begin{array}{c}0.539 \\
(0.517 \div 0.65) \text { * }\end{array}$ & $\begin{array}{c}0.00 \\
(0 \div 0.014) *\end{array}$ & $\begin{array}{c}0.551 \\
(0.4137 \div 0.62)^{*}\end{array}$ & $\begin{array}{c}0.539 \\
(0.517 \div 0.65)^{*}\end{array}$ & $\begin{array}{c}0.00 \\
(0 \div 0.014)^{*}\end{array}$ \\
\hline $\begin{array}{c}D \\
126 \mathrm{~km} / \mathrm{h}\end{array}$ & 4th+ lockup & $\begin{array}{c}0.00 \\
(0 \div 0.014)^{*}\end{array}$ & $\begin{array}{c}0.527 \\
(0.517 \div 0.65)^{*}\end{array}$ & $\begin{array}{c}0.00 \\
(0 \div 0.014)^{*}\end{array}$ & $\begin{array}{c}0.00 \\
(0 \div 0.034)^{*}\end{array}$ & $\begin{array}{c}\mathbf{0 . 5 3 9} \\
(0.517 \div 0.65) \text { * }\end{array}$ & $\begin{array}{c}0.00 \\
(0 \div 0.014)^{*}\end{array}$ \\
\hline
\end{tabular}

\section{SUMMARY}

The built stand lets evaluate the automatic gearboxes operation, mainly in terms of mechanic and hydraulic systems, using in controlling the own acting system. Possible measurements and tests to perform:

- shifting gears in automatic or manual mode,

- correctness of gearbox operation with cold or hot oil,

- leak tightness of executing elements of hydraulic steering system,

- correctness of oil pump operation - oil pressing test,
- elaboration of operation loudness: fluid coupling, pump, clutches or planetary gear systems,

- correctness of operation at established, constant gearbox operation parameters,

- test checking the solenoid valves operation, fluid coupling (lock - up engaging),

- measurement of operation oil temerature,

- measurement of output rotational speed on output transmission shaft on each gearing,

- measurement of torque on transmission input and output shaft. 
The built stand can be used for research purposes, as well as the base for mathematical models verification, describing the researched system operation. It is also possible to use it in gearbox diagnosis after the repair, before mounting in the vehicle. Given results are presented in graphic form or as the data stored in tables, depending on individual needs of person who diagnoses the gearbox. The stand can be fitted to individual needs of every service or workshop.

\section{REFERENCES}

1. Automatic Transmission Service Group: Introduction: Chrysler A 604, Florida $1994-2005$.

2. Bemporad A., Borodani P., Mannelli M. (2003), Hybrid control of an automotive robotized gearbox for reduction of consumptions and emissions, 6th International Workshop on Hybrid Systems Computation and Control (HSCC 2003), Prague, Czech Republic, Apr 03 - 05, Edited by: Maler O., Pnueli A., Hybrid systems: Computation and control proceedings, Vol. 2623, 81 - 96.

3. Bosch Folders (2005), Elektronic steering of EGS gearbox, WKL, Warsaw

4. Bozca M. (2010), Torsional vibration model based optimization of gearbox geometric design parameters to reduce rattle noise in an automotive transmission, Mechanism and Machine Theory, Vol. 45, 1583-1598.

5. Haj - Fraj A., Pfeiffer F. (2001), Optimal control of gear shift operations in automatic transmissions, Journal of the Franklin Institute, Vol. 338, 371-390.

6. Advanced Digital Technology Co. Ltd. (2014), http://adigitec.com/ data/ADT\%20Brochure\%20130215\%20Light\%20version.pdf.

7. FEV GmbH(2014), http://www.fev.com/fileadmin/fev-resources/ Teclinfo/Test_System/173_Teclnfo_FEV_Transmission_Test Bench.pdf.

8. Klotz GmbH (2014), http://www.klotz.de/en/measurement testing/ automatic transmissions.html.

9. Mustang Advanced Engineering (2014), http://www.mustangdyne. com/mustangae/wp - content/uploads/downloads/2011/03/MAE transmission2012.pdf.

10. International Corporate Headquarters, Power Test, Inc. (2014), http://www.pwrtst.com/transmission/test - stand.htm\#.

11. SuperFlow Dynamometers \& Flowbenches(2014), http://www.superflow.com/Dynamometers/transmission/edect.php.

12. Kulkarni M., Shim T., Zhang Y. (2007), Shift dynamics and control of dual - clutch transmissions, Mechanism and Machine Theory, Vol. 42, 168-182
13. Merkisz J., Mazurek S. (2006), OBDII EOBD On - board diagnostics, WKL, Warszawa.

14. Ognjanovic M., Milutinovic M. (2013), Design for Reliability Based Methodology for Automotive Gearbox Load Capacity Identification, Strojniški vestnik - Journal of Mechanical Engineering, Vol. 59/5, $311-322$.

15. Remond D., Soleilhac P., Play D., Coppens P., Villars F. (1998), Transmission error measurements on automotive gearbox, Mechanique Inustielle et ma Materiaux, Vol. 51/2, 61 - 63.

16. Rumble A. W. (2000), Techniques for enhancing correlation between objective tonal noise measurements from automotive transmissions on test stands and subjective assessments in - vehicle, IMECHE Vehicle Noise and Vibration, Vol. 2000/1, 127 - 137.

17. Ślaski G. (2010), Savings the fuels due to modern solutions in automatic gearboxes, InterdisciplinaryScientific Conference Ecological and Energetic Threats and New Challenges materials, PWSZ, Gniezno, $64-74$.

18. Ślaski G. (2012), The purposefulness of application and control issues of friction brake within test bench simulation reproducing the drivetrain dynamics, The Archives of Automotive Engineering, 4/58, $57-66$

19. Ślaski G., Walkowiak J. (2011), Test bench simulation reproducing the drivetrain dynamics of a car with automatic transmission - control and results of experimental tests, The Archives of Automotive Engineering, 3/53, $61-80$.

20. Sobieraj W. (2005), Automatic gearboxes, Instalator Polski, 4.

21. Walker P. D., Zhang N., Tamba R. (2011), Control of gear shifts in dual clutch transmission powertrains, Mechanical Systems and Signal Processing, Vol. 25, 1923-1936

22. Wen - Miin H., Yu - Lien H. (2011), Connecting clutch elements to planetary gear trains for automotive automatic transmissions via coded sketches, Mechanism and Machine Theory, Vol 46, 44-52.

The investigations described in this paper are a part of the research project No S/WM/2/13 realized at Białystok University of Technology. 